\title{
Adamantane ionic liquids
}

\section{AUTHOR(S):}

Tanaka, Kazuo; Hiraoka, Tatsuhiro; Ishiguro, Fumiyasu; Jeon, Jong-Hwan; Chujo, Yoshiki

\section{CITATION:}

Tanaka, Kazuo ... [et al]. Adamantane ionic liquids. RSC Advances 2014, 4(53): 28107-28110

\section{ISSUE DATE:}

2014-06-30

URL:

http://hdl.handle.net/2433/200235

\section{RIGHT:}

This journal is (C) The Royal Society of Chemistry 2014.; This is not the published version. Please cite only the published version.; この論文は 出版社版でありません。引用の際には出版社版をご確認ご利用くださ い。 


\title{
Adamantane Ionic Liquids
}

\author{
Kazuo Tanaka, Tatsuhiro Hiraoka, Fumiyasu Ishiguro, Jong-Hwan Jeon, Yoshiki Chujo* \\ Receipt/Acceptance Data [DO NOT ALTER/DELETE THIS TEXT] \\ Publication data [DO NOT ALTER/DELETE THIS TEXT] \\ 5 DOI: 10.1039/b000000x [DO NOT ALTER/DELETE THIS TEXT]
}

We report synthesis and characteristic thermal properties of the adamantane-based ionic salts. The ion salts with adamantane carboxylates and imidazolium cations were prepared via neutralization. It was found that the assembly of the ion pairs on 10 the adamantane core can improve the thermal stability and lower melting temperatures even though the molecular weight increases. Finally, the thermally-stable room temperature-ionic liquids, which are defined as a salt with the melting temperature below $25{ }^{\circ} \mathrm{C}$, can be obtained based on adamantane. The 15 tetrahedral-like distribution of ion pairs could be responsible for simultaneously improving thermal stability and lowering melting temperatures of ion pairs.

Ionic liquids (ILs) which are defined as the salt with melting temperatures below $100{ }^{\circ} \mathrm{C}$ attract attention for the application in 20 various fields because of their wide versatility. For example, some of ILs have high ion conductivity and flame resistance. ${ }^{[1,2]}$ Based on these characteristics, ILs have been attempted to be applied as an electrolyte in a lithium battery. ${ }^{[3]}$ In addition, the material properties of ILs can be readily tuned by changing component ions. ${ }_{25}$ Recently, we reported the modulation of dispersibility of the ILmodified metal nanoparticles. ${ }^{[4,5]}$ By the anion exchange of ILs at the surface of the particles, the compatibility with solvent molecules was greatly changed. As a result, the dispersion/aggregation of the nanoparticles can be controlled under 30 mild conditions. Moreover, by altering the affinity to DNA, the catch and release system for DNA can be accomplished by anion exchange. ${ }^{[6]}$ Thus, the development of new component molecules has large potential to produce new series of ILs. In particular, since the anion species significantly influence on the properties of ILs, 35 the synthesis of new anions with bulky structures is of great significance for obtaining advanced functionalized ILs as well as desired materials. ${ }^{[7]}$

In general, the increase of molecular weight of components tends to increase melting temperatures of ion pairs. Therefore, there 40 is fewer ILs with multiple ion pairs in the single molecule comparing to those with a single ion pair. We have recently found that the thermal properties of ion pairs were crucially changed by tethering to the vertices of polyhedral oligomeric silsesquioxane (POSS, Figure 1) ${ }^{[8,9]}$ : Melting temperatures of the POSS-tethered 45 ion pairs can be reduced by inhibiting molecular interaction because of the isolation effect by the cubic core. Moreover, thermal

Department of Polymer Chemistry

Graduate School of Engineering, Kyoto University

Katsura, Nishikyo-ku, Kyoto 615-8510 Japan

Fax: (+81) 75-383-2605

E-mail: chujo@chujo.synchem.kyoto-u.ac.jp

† Electronic Supplementary Information (ESI) available: [details of any supplementary information available should be included here]. See http://dx.doi.org/10.1039/b000000x/

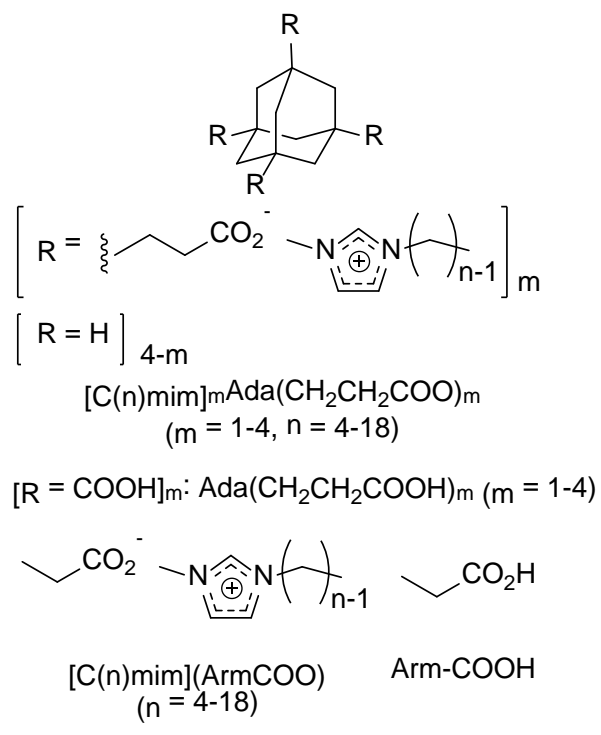

Fig. 1 Chemical structures and abbreviations of the ion salts used in this study. The number of ion pairs around the adamantane core and the length of the alkyl chain in methyl imidazolium are represented as $m$ and $n$, respectively.

stability can be improved by suppressing molecular motions by the rigid silica cube and highly-symmetrical structure of POSS. Finally, despite there are eight ion pairs in the single molecule, we obtained 50 the room temperature-ILs which have the melting temperature below $25{ }^{\circ} \mathrm{C} .{ }^{[8,9]}$ More recently, the molecular filler for enhancing thermal stability and lowering melting temperature of conventional ILs was presented. ${ }^{[10]}$ According to these results, we suggested that the introduction of the rigid and symmetrical core could be 55 essential to reduce melting temperatures and enhance thermal stability of ion pairs for obtaining ILs based on polymers or macromolecules. To show the generality of this suggestion, the other example should be offered as the ILs having multiple ion pairs tethered to the rigid steric core.

60 We focused on adamantane as a core for assembling ion pairs. Adamantane possesses the minimum unit structure of a diamond crystal and therefore has been used as a building block for constructing thermally-stable or robust materials. ${ }^{[11]}$ Furthermore, each ion pair should be located as tetrahedral-like distribution 65 around the adamantane core by tethering to the vertices of adamantane. Thereby, adamantane should be a good example as a scaffold to evaluate the steric core effect on the thermal properties of ion pairs. Herein, we report the characteristic thermal properties of the adamantane-tethered ion salts (Figure 1). The series of ion 70 salts with adamantane carboxylates and imidazolium cations were prepared. The influence of chemical structures of adamantanebased salts on melting temperatures and thermal stability was investigated with various numbers of ion pairs around the 
Table 1 Melting and decomposition temperatures of the tetra-substituted ion salts

\begin{tabular}{cccccccc}
\hline & \multicolumn{3}{c}{$T_{\mathrm{m}}\left({ }^{\circ} \mathrm{C}\right)^{a}$} & & \multicolumn{3}{c}{$T_{\mathrm{d}}\left({ }^{\circ} \mathrm{C}\right)^{b}$} \\
\cline { 2 - 3 } \cline { 6 - 7 } $\mathrm{C}_{\mathrm{n}}$ & Ada & Arm & $\Delta$ & & Ada & Arm & $\Delta$ \\
\hline 4 & 31 & n.d. ${ }^{c}$ & - & & 224 & 217 & +7 \\
6 & 27 & n.d. $^{c}$ & - & & 223 & 214 & +9 \\
8 & n.d. $^{c}$ & n.d. $^{c}$ & - & & 225 & 220 & +5 \\
10 & n.d. $^{c}$ & 26 & - & & 219 & 218 & +1 \\
12 & 21 & 40 & -19 & & 220 & 218 & +2 \\
14 & n.d. ${ }^{c}$ & 56 & - & & 232 & 217 & +15 \\
16 & 31 & 65 & -34 & & 249 & 217 & +32 \\
18 & 41 & 73 & -32 & & 253 & 221 & +32
\end{tabular}

${ }^{a}$ Obtained from the first heating curves in the DSC profiles.

${ }^{b}$ Determined from the onsets in the TGA curves.

${ }^{c}$ n.d. $=$ not determined.

Table 2 Melting and decomposition temperatures of $[\mathrm{C}(\mathrm{n}) \mathrm{mim}]_{\mathrm{m}} \mathrm{Ada}\left(\mathrm{CH}_{2} \mathrm{CH}_{2} \mathrm{COO}\right)_{\mathrm{m}}$

\begin{tabular}{cccccccc}
\hline & \multicolumn{3}{c}{$T_{\mathrm{m}}\left({ }^{\circ} \mathrm{C}\right)^{a}$} & & \multicolumn{3}{c}{$T_{\mathrm{d}}\left({ }^{\circ} \mathrm{C}\right)^{b}$} \\
\cline { 2 - 3 } \cline { 6 - 8 } & $\mathrm{C} 4$ & $\mathrm{C} 10$ & $\mathrm{C} 18$ & & $\mathrm{C} 4$ & $\mathrm{C} 10$ & $\mathrm{C} 18$ \\
\hline 1 & 48 & n.d. $^{c}$ & 18 & & 215 & 222 & 224 \\
2 & n.d. $^{c}$ & 19 & 31 & & 222 & 223 & 237 \\
3 & n.d. $^{c}$ & 16 & 40 & & 219 & 223 & 243 \\
4 & 31 & n.d. $^{c}$ & 41 & & 223 & 219 & 253
\end{tabular}

${ }^{a}$ Obtained from the first heating curves in the DSC profiles.

${ }^{b}$ Determined from the onsets in the TGA curves.

${ }^{c}$ n.d. $=$ not determined.

adamantane core and lengths of the alkyl chains in imidazolium

75 cation. The roles of the structural feature of the adamantane core are evaluated from the experiments.

Synthesis of the series of adamantane-based salts was carried out according to the previous reports. ${ }^{[12-14]}$ The precursors of adamantane with various numbers of carboxylic groups, ${ }_{80} \mathrm{Ada}\left(\mathrm{CH}_{2} \mathrm{CH}_{2} \mathrm{COOH}\right)_{\mathrm{m}}(\mathrm{m}=1,2,3$ and 4$)$, were obtained by modulating the feed ratio of bromine in bromination. After treating with acrylonitrile, hydrolysis provided $\mathrm{Ada}\left(\mathrm{CH}_{2} \mathrm{CH}_{2} \mathrm{COOH}\right)_{\mathrm{m}}$ with high purity. The series of the hydroxyl form of imidazolium salts with a methyl group and various lengths of alkyl chains (C4 to

${ }_{85} \mathrm{C} 18$ ) were prepared via anion exchange from bromide salts which were synthesized under mild conditions to avoid the contamination of colored impurities. The neutralization was employed for receiving ion pairs by mixing the imidazolium salt with $\mathrm{Ada}\left(\mathrm{CH}_{2} \mathrm{CH}_{2} \mathrm{COOH}\right)_{\mathrm{m}}$ in methanol. After drying in vacuo, desired 90 salts $[\mathrm{C}(\mathrm{n}) \mathrm{mim}]_{\mathrm{m}} \mathrm{Ada}\left(\mathrm{CH}_{2} \mathrm{CH}_{2} \mathrm{COO}\right)_{\mathrm{m}}(\mathrm{m}=1-4, \mathrm{n}=4-18)$ were obtained as colorless and transparent products. We also prepared the ion pairs with propionic acid, [C(n)mim](ArmCOO) $(n=4-18)$, for the comparison to evaluate the effects of the connection to adamantane.

${ }_{95}$ By comparing integration ratios of the peaks in the ${ }^{1} \mathrm{H}$ NMR spectra, the formation of a one-to-one pair between the carboxylate in adamantane and imidazolium cation was confirmed. The products were stored in a glove box under argon atmosphere, and water abundance can be kept below $1.5 \mathrm{wt} \%$ as determined by the

100 Karl Fischer method. From previous reports, it was confirmed that the concentrations of residual bromide ion in imidazolium hydroxides were lower than the detectable level in the elemental analysis. ${ }^{[8,9]}$ Therefore, we summarized that all products were enough purity for evaluating thermal properties.

${ }_{105}$ The $T_{\mathrm{ms}}$ of $[\mathrm{C}(\mathrm{n}) \mathrm{mim}]_{4} \mathrm{Ada}\left(\mathrm{CH}_{2} \mathrm{CH}_{2} \mathrm{COO}\right)_{4}$ and $[\mathrm{C}(\mathrm{n}) \mathrm{mim}]($ ArmCOO) were initially compared from DSC measurements with a heating rate of $10{ }^{\circ} \mathrm{C} / \mathrm{min}$. The values of the obtained compounds are listed in Table 1 . Interestingly, the series of $[\mathrm{C}(\mathrm{n}) \mathrm{mim}]_{4} \mathrm{Ada}\left(\mathrm{CH}_{2} \mathrm{CH}_{2} \mathrm{COO}\right)_{4}$ showed the endothermic peaks

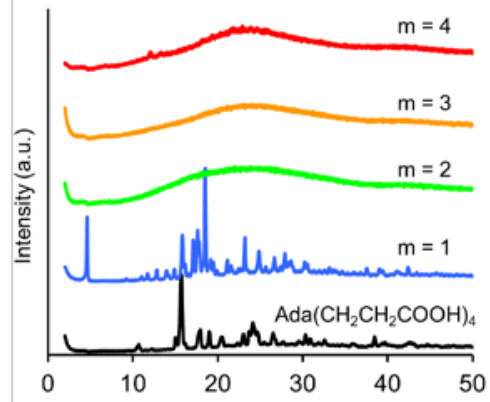

Fig. 2 XRD patterns of the $[\mathrm{C}(4) \mathrm{mim}]_{\mathrm{m}} \mathrm{Ada}\left(\mathrm{CH}_{2} \mathrm{CH}_{2} \mathrm{COO}\right)_{\mathrm{m}}$.

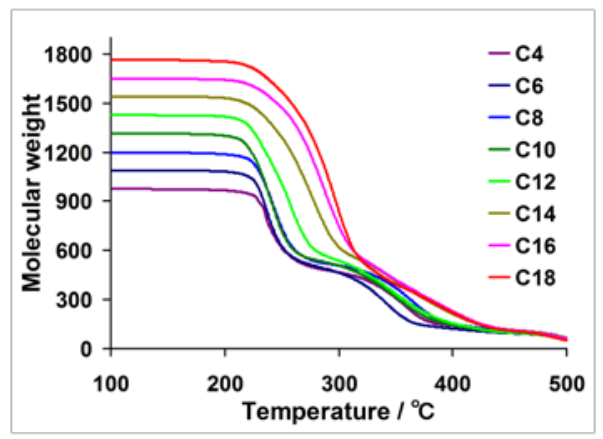

Fig. 3 TGA thermograms of the $[\mathrm{C}(\mathrm{n}) \operatorname{mim}]_{4} \mathrm{Ada}\left(\mathrm{CH}_{2} \mathrm{CH}_{2} \mathrm{COO}\right)_{4}$ under flowing nitrogen. The $T_{\mathrm{d}}$ values were determined from the onset of the curve.

110 assigned as the melting process below $100{ }^{\circ} \mathrm{C}$. These data are the direct evidence that the adamantane-based salts are an IL. In particular, $[\mathrm{C}(12) \mathrm{mim}]_{4} \mathrm{Ada}\left(\mathrm{CH}_{2} \mathrm{CH}_{2} \mathrm{COO}\right)_{4}$ was melted at $21{ }^{\circ} \mathrm{C}$. This result represents that the room temperature-IL can be obtained. Furthermore, $[\mathrm{C}(\mathrm{n}) \mathrm{mim}]_{4} \mathrm{Ada}\left(\mathrm{CH}_{2} \mathrm{CH}_{2} \mathrm{COO}\right)_{4}$ showed lower $T_{\mathrm{mS}}$ 115 than those of $[\mathrm{C}(\mathrm{n}) \mathrm{mim}]($ ArmCOO) with corresponded length of alkyl chains. These results suggest that the adamantane core should play a significant role in the decrease of the $T_{\mathrm{m}}$ of ion pairs. The decrease on the $T_{\mathrm{ms}}$ of ion pairs should be related with the increase of the rotational degree's of freedom of the $-\mathrm{CH}_{2} \mathrm{CH}_{2} \mathrm{COO}^{-}$.

120 Next, we measured the $T_{\mathrm{mS}}$ of $[\mathrm{C}(\mathrm{n}) \mathrm{mim}]_{\mathrm{m} A d a}\left(\mathrm{CH}_{2} \mathrm{CH}_{2} \mathrm{COO}\right)_{\mathrm{m}}$ ( $m=1-4, n=4,10$, and 18) to evaluate the effect by changing the number of ion pairs around the adamantane core (Table 2). In the case of POSS-ILs, the number of ion pairs around the core greatly influenced on the thermal properties of ion pairs. ${ }^{[8,9]}$ In summary, 125 when the larger number of ion pairs are accumulated on POSS, the $T_{\mathrm{ms}}$ decreased. Similar results with the POSS-ILs were obtained from the adamantane ILs. [C(4)mim $]_{4} \mathrm{Ada}\left(\mathrm{CH}_{2} \mathrm{CH}_{2} \mathrm{COO}\right)_{4}$ and [C(10)mim $]_{3} \mathrm{Ada}\left(\mathrm{CH}_{2} \mathrm{CH}_{2} \mathrm{COO}\right)_{3}$ possessed the lower $T_{\mathrm{m}}$ by $17{ }^{\circ} \mathrm{C}$ and $3{ }^{\circ} \mathrm{C}$ than that of $[\mathrm{C}(4) \mathrm{mim}] \mathrm{Ada}\left(\mathrm{CH}_{2} \mathrm{CH}_{2} \mathrm{COO}\right)$ and $130[\mathrm{C}(10) \mathrm{mim}]_{2} \mathrm{Ada}\left(\mathrm{CH}_{2} \mathrm{CH}_{2} \mathrm{COO}\right)_{2}$, respectively. The same explanation with the cubic core could be applicable on the decreases of $T_{\mathrm{ms}}$ by increasing the number of ion pairs around the adamantane core ${ }^{[9]}$ : By locating each ion pair at the vertices, the interaction should be suppressed. Moreover, sphere-like whole 135 structures of the adamantane molecules could possess large exclusive volumes, leading to the reduction of intermolecular interaction. Hence, $T_{\mathrm{ms}}$ are reduced. The $T_{\mathrm{ms}}$ of adamantane ILs with $\mathrm{C}_{18}$ alkyl chain increase by adding the number of ion pairs. It is implied that the interaction among long alkyl chains might be 140 generated, resulting in the enhancement of the $T_{\mathrm{ms}}$. Similar tendencies were observed from the glass transition temperatures 
$\left(T_{\mathrm{g}} \mathrm{S}\right)$ as shown in Tables S1 and S2. These data support the effect of the adamantane core on the thermal properties.

To investigate the packing of the adamantane derivatives in the 145 solid states, XRD analyses were executed (Figure 2). $[\mathrm{C}(4) \mathrm{mim}]_{4} \mathrm{Ada}\left(\mathrm{CH}_{2} \mathrm{CH}_{2} \mathrm{COO}\right)_{4}, \quad[\mathrm{C}(4) \mathrm{mim}]_{3} \mathrm{Ada}\left(\mathrm{CH}_{2} \mathrm{CH}_{2} \mathrm{COO}\right)_{3}$ and $[\mathrm{C}(4) \mathrm{mim}]_{2} \mathrm{Ada}\left(\mathrm{CH}_{2} \mathrm{CH}_{2} \mathrm{COO}\right)_{2}$, showed the typical spectra as amorphous compounds. On the other hand, the dispersed patterns were observed from [C(4)mim]Ada $\left(\mathrm{CH}_{2} \mathrm{CH}_{2} \mathrm{COO}\right)$ as well as $150 \mathrm{Ada}\left(\mathrm{CH}_{2} \mathrm{CH}_{2} \mathrm{COO}\right)_{4}$. The solid state of [C(4)mim] Ada $\left(\mathrm{CH}_{2} \mathrm{CH}_{2} \mathrm{COO}\right)$ should involve the regular structure similarly as $\mathrm{Ada}\left(\mathrm{CH}_{2} \mathrm{CH}_{2} \mathrm{COO}\right)_{4}$, while the increase of the number of ion pairs around the adamantane core should disturb the formation of the ordering structures. These data are corresponded to 155 the results from the melting behaviors. The larger numbers of ion pairs around the adamantane core can disturb the crystalline formation and produce exclusive volumes. Thereby, the $T_{\mathrm{ms}}$ of [C(4)mim $]_{4} \mathrm{Ada}\left(\mathrm{CH}_{2} \mathrm{CH}_{2} \mathrm{COO}\right)_{4}$

and

[C(4)mim $]_{3} \mathrm{Ada}\left(\mathrm{CH}_{2} \mathrm{CH}_{2} \mathrm{COO}\right)_{3}$ decreased. On the other hand, in 160 the case of [C(4)mim] Ada $\left(\mathrm{CH}_{2} \mathrm{CH}_{2} \mathrm{COO}\right)$, aggregation could occur because of the strong hydrophobic interaction and the symmetric structure of the adamantane core. Thus, the crystal structures should be partially grown in the solid states similarly as that from $\mathrm{Ada}\left(\mathrm{CH}_{2} \mathrm{CH}_{2} \mathrm{COO}\right)_{4}$.

165 The influence on thermal stability of [C(n)mim $]_{4} \mathrm{Ada}\left(\mathrm{CH}_{2} \mathrm{CH}_{2} \mathrm{COO}\right)_{4}$ and [C(n)mim](ArmCOO) against pyrolysis was investigated. From the onsets of TGA curves, the $T_{\mathrm{d}}$ values were determined (Table 1). Two large weight losses were observed around $230{ }^{\circ} \mathrm{C}$ and $350{ }^{\circ} \mathrm{C}$ from both of adamantane and ${ }_{170}$ Arm salts (Figure 3). After the first weight loss, similar molecular weights were obtained. These data suggest that the pyrolysis should initially proceed at imidazolium cations. Two significant tendencies can be obtained from the series of $T_{\mathrm{d} S}$ : [C(n)mim $]_{4} \mathrm{Ada}\left(\mathrm{CH}_{2} \mathrm{CH}_{2} \mathrm{COO}\right)_{4}$ showed higher $T_{\mathrm{d}}$ than those of 175 [C(n)mim](ArmCOO) with corresponded length of alkyl chains. This fact clearly indicates that the connection of ion pairs to the adamantane core should be responsible for the enhancement of thermal stability of ion pairs. The rigid diamond-like structure of adamantane could efficiently suppress molecular motions of ion 180 pairs. In addition, by elongating the alkyl chain in [C(n)mim $]_{4} \mathrm{Ada}\left(\mathrm{CH}_{2} \mathrm{CH}_{2} \mathrm{COO}\right)_{4}$, the $T_{\mathrm{d}}$ values significantly increased. This phenomenon was not observed from [C(n)mim](ArmCOO) and POSS-ILs. ${ }^{[8,9]}$ This is the characteristic feature obtained only from adamantane. The interaction between 185 the alkyl chains of imidazolium cation and the adamantane core might occur via hydrophobic interaction. Thereby, the thermal stability could be reinforced.

The thermal stability with $[\mathrm{C}(\mathrm{n}) \mathrm{mim}]_{\mathrm{m}} \mathrm{Ada}\left(\mathrm{CH}_{2} \mathrm{CH}_{2} \mathrm{COO}\right)_{\mathrm{m}}(\mathrm{m}=$ $1-4, n=4,10$, and 18) was evaluated (Table 2). The increase of $T_{\mathrm{d}}$ 190 was observed from $[\mathrm{C}(18) \mathrm{mim}]_{\mathrm{mAda}}\left(\mathrm{CH}_{2} \mathrm{CH}_{2} \mathrm{COO}\right)_{\mathrm{m}}$ corresponded to the increase of the number of ion pairs. $[\mathrm{C}(18) \mathrm{mim}]_{3} \mathrm{Ada}\left(\mathrm{CH}_{2} \mathrm{CH}_{2} \mathrm{COO}\right)_{3}$

and [C(18)mim $]_{4} \mathrm{Ada}\left(\mathrm{CH}_{2} \mathrm{CH}_{2} \mathrm{COO}\right)_{4}$ showed higher $T_{\mathrm{ds}}$ by $24{ }^{\circ} \mathrm{C}$ and $30{ }^{\circ} \mathrm{C}$ than those of $[\mathrm{C}(4) \mathrm{mim}]_{3} \mathrm{Ada}\left(\mathrm{CH}_{2} \mathrm{CH}_{2} \mathrm{COO}\right)_{3}$ and $195[\mathrm{C}(4) \mathrm{mim}]_{4} \mathrm{Ada}\left(\mathrm{CH}_{2} \mathrm{CH}_{2} \mathrm{COO}\right)_{4}$, respectively. The longer alkyl chains should be favorable to suppress molecular motions of ion pairs, leading to the inhibition of pyrolysis.

In conclusion, we demonstrate the characteristic thermal properties of adamantane-based salts. Assembly of ion pairs on the 200 adamantane core improves the thermal stability and lower melting temperatures even though the molecular weights of the components are large. Finally, the adamantane-based room temperature-ILs can be obtained. In addition, these ILs showed higher thermal stability. From the comparison study on thermal properties with the 205 adamantane salts with various numbers of ion pairs around adamantane and lengths of alkyl chains in imidazolium cation, two significant issues were suggested: The tetrahedral-shaped distribution of ion pairs could be critical for simultaneously improving thermal stability and lowering melting temperatures. In 210 addition, the adamantane core could have larger ability to interact with the alkyl chains in imidazolium cations than that of POSS. Therefore, the adamantane ILs with long alkyl chains showed high thermal stability. Our findings described here are feasible for establishing the strategy for preparing heat-resisting ILs based on 215 polymers or macromolecules.

This work was partially supported by a Grant-in-Aid for Scientific Research on Innovative Areas "New Polymeric Materials Based on Element-Blocks (No.2401)” (25102521) of The Ministry of Education, Culture, Sports, Science, and Technology, Japan.

\section{References}

1 (a) A. Fernicola, B. Scrosati and H. Ohno, Ionics, 2006, 12, 95-102. (b) M. Armand, F. Endres, D. R. MacFarlane, H. Ohno and B. Scrosati, Nat. Mater., 2009, 8, 621-629.

2 (a) T. Ogoshi, N. Ueshima, T. Yamagishi, Y. Toyota and N. Matsumi, Chem. Commun., 2012, 48, 3536-3538. (b) T. Ogoshi, T. Onodera, T. Yamagishi, Y. Nakamoto, A. Kagata, N. Matsumi and K. Aoi, Polym. J., 2011, 43, 421-424.

3 (a) T. Mizumo, R. Fujita, H. Ohno and J. Ohshita, Chem. Lett., 2011, 40, 798-800. (b) Q. Zhou, W. A. Henderson, G. B. Appetecchi and S. Passerini, J. Phys. Chem. C., 2010, 114, 6201-6204. (c) J. M. Pringle, P. C. Howlett, D. R. MacFarlane and M. Forsyth, J. Mater. Chem., 2010, 20, 2056-2062. (d) V. Chakrapani, F. Rusli, M. A. Filler and R. A. Kohl, J. Phys. Chem. C., 2011, 115, 22048-22053. (e) Q. Zhou, P. D. Boyle, L. Malpezzi, A. Mele, J. H. Shin, S. Passerini and W. A. Henderson, Chem. Mater., 2011, 23, 4331-4337. (f) W. Weng, Z. Zhang, J. Lu and K. Amine, Chem. Commun., 2011, 47, 1196911971. (g) H. Yoon, G. H. Lane, Y. Shekibi, P. C. Howlett, M. Forsyth, A. S. Best and D. R. MacFarlane, Energy Environ. Sci., 2013, 6, 979-986.

2404 E. Miyoshi, K. Naka, K. Tanaka, A. Narita and Y. Chujo, Colloids Surf., A, 2011, 390, 126-133.

5 K. Tanaka, A. Narita, K. Suzuki and Y. Chujo, Compos. Interface., 2013, 20, 557-564.

6 K. Tanaka, A. Narita and Y. Chujo, Compos. Interface., 2013, 20, $245 \quad 27-32$

7 (a) K. Nobuoka, S. Kitaoka, M. Iio, T. Harran and Y. Ishikawa, Phys. Chem. Chem. Phys., 2007, 9, 5891-5896. (b) K. Nobuoka, S. Kitaoka, K. Kunimitsu, N. Iio, T. Harran, A. Wakisaka and Y. Ishikawa, J. Org. Chem., 2005, 70, 10106-10108.

2508 K. Tanaka, F. Ishiguro and Y. Chujo, J. Am. Chem. Soc., 2010, 132, 17649-17651.

9 K. Tanaka, F. Ishiguro and Y. Chujo, Polym. J., 2011, 43, 708-713.

10 (a) J. H. Jeon, K. Tanaka and Y. Chujo, RSC Adv., 2013, 3, 24222427. (b) J. H. Jeon, K. Tanaka and Y. Chujo, J. Mater. Chem. A, $255 \quad$ 2014, 2, 557-868.

11 (a) J. E. Dahl, S. G. Liu and R. M. K. Carlson, Science, 2003, 299, 96-99. (b) S. Inomata, Y. Harada, Y. Nakamura, Y. Uehara and T. Ishizone, J. Polym. Sci. A; Polym. Chem., 2013, 51, 4111-4124. (c) S. Inomata, S. Matsuoka, S. Sakai, H. Tajima and T. Ishizone, Macromolecules, 2012, 45, 4184-4195. (d) S. Matsuoka, N. Ogiwara and T. Ishizone, J. Am. Chem. Soc., 2006, 128, 8708-8709. (e) H. Kubo, N. Niina, T. Sato, H. Oizumi, T. Itani, T. Miura, T. Watanabe and H. Kinoshita, J. Photopolym. Sci. Technol., 2012, 25, 587-592. (f) T. Gushiken, S. Ujiie, T. Ubukata and Y. Yokoyama, Bull. Chem. Soc. Jpn., 2011, 84, 269-282. (g) M. Kanao, A. Otake, K. Tsuchiya 
and K. Ogino, J. Photopolym. Sci. Technol., 2011, 24, 361-366. (h) S. U. Lee, H. Mizuseki and Y. Kawazoe, Phys. Chem. Chem. Phys., 2010, 12, 11763-11769. (i) S. Yasuda, A. Takahashi, T. Oyama and S. Yamao, J. Photopolym. Sci. Technol., 2010, 23, 511-514.

27012 G. S. Lee, J. N. Bashara, G. Sabih, O. Asmik, G. Godjoian, H. M. Duong, E. R. Marinez and G. C. Gutiéles, Org. Lett., 2004, 6, 1705-1707.

13 P. Nadine and M. Wolfgang, Eur. J. Org. Chem., 2008, 2008, 1278-1284.

27514 R. E. Delimarskii, V. N. Rodionov and A. G. Yurchenko, Ukr. Khim. Zh. (Russ. Ed.), 1988, 54, 437-438. 